\title{
Innovation in Russian District Heating: Opportunities, Barriers, Mechanisms*
}

\author{
Andrey Kovalev, Liliana Proskuryakova
}

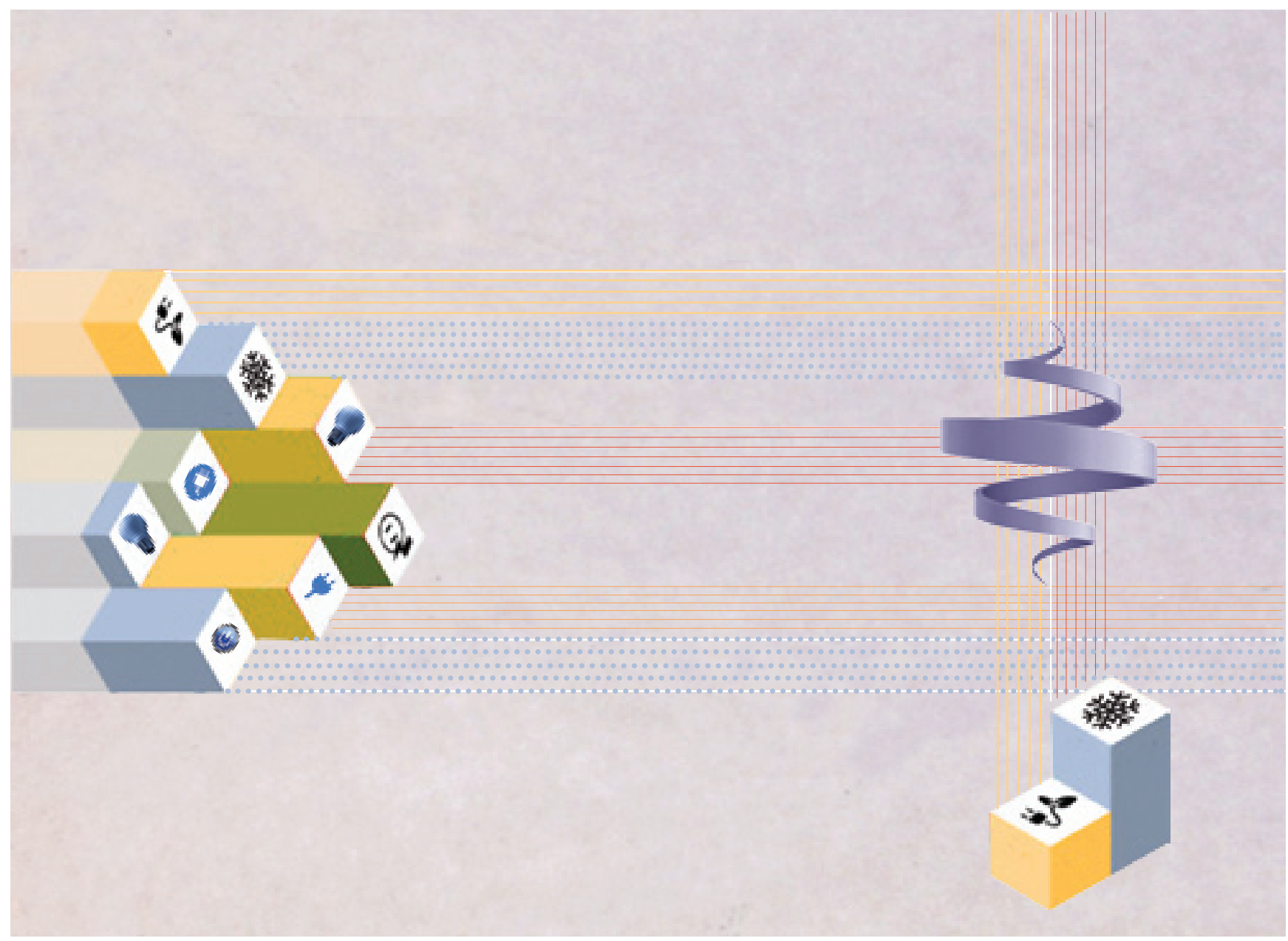

Contrary to the advanced countries, heat energy sector in Russia hardly embraces radical innovations. Moscow heat supply system, the most innovative comparing to that of other Russian cities, is no exception. It focuses on incremental innovations while lagging in radical innovations in cogeneration, trigeneration etc.

The paper considers the reasons for such a situation, compares Russian and European heating markets and corporate strategies, provides recommendations for supporting the innovative development of Russian heating companies.
Andrey Kovalev - Independent Expert.

E-mail: and.v.kovalev@gmail.com

Liliana Proskuryakova - Senior Research Fellow, Research Laboratory for Science and Technology Studies, HSE ISSEK. Address: 11, Myasnitskaya str., Moscow 101000, Russian Federation. E-mail: lproskuryakova@hse.ru

\section{Keywords}

heat generation; heat supply; power generation; open innovation; labor productivity; knowledge management

Citation: Kovalev A., Proskuryakova L. (2014) Innovation in the Russian Heating Utilities: Opportunities, Barriers, Mechanisms. Foresight-Russia, vol. 8, no 3, pp. 42-57.

The paper was prepared within the framework of the project «Establishing the system of tools for the embedding outputs of industry S\&T forecasts into the preparation and revision of the Russian Long-term S\&T Foresight», supported by the Ministry of Education and Science of the Russian Federation (a unique identifier of research work RFMEFIC CC14X0002). 
D istrict heating in Russia accounts ${ }^{1}$ for roughly $44 \%$ of the world's total heat production capacity, and if small boilers are included, its share is even greater [Kozhukhovskii, 2013]. Local monopolies prevail in Russian district heating, while in other countries distributed heat generation exists in more balanced proportions. Erroneous managerial strategies (including strategies for innovative development) can potentially lead to greater costs in such systems than in a competitive market environment. In recent decades, this field has accumulated problems such as wear and tear on equipment, heat losses, and low efficiency of heat sources [Ministry of Energy, 2013; Begalov, 2013]. The situation is compounded by a number of systemic factors [IFC, World Bank, 2008], including the lack of innovative development at most district heating companies. Their activities mainly target maintaining the technological process under conditions of highly depreciated equipment and delayed payments from customers. An exception is the metropolitan district heating system where a key organization - Moskovskaya Ob'edinennaya Energenticheskaya Kompaniya (Moscow Integrated Power Company, MIPC) - is focused on implementing innovations [MIPC, 2011b, 2013a]. For this reason, an analysis of the features of the metropolitan heating industry's innovative development makes it possible to formulate recommendations that may be sought after by other heating companies.

This paper examines the innovative development of Moscow's district heating system enterprises. Equipment availability, financial support, and strict compliance with technical regulations in municipal heating supply make it possible to eliminate subjective factors that are typical for many regional companies and have caused them to lag behind technologically. This has allowed us to focus our research on the strategic aspects of innovative activities instead of the traditional discussion of current problems. We present the sector's development strategy in recent decades and the results of innovative activities conducted by companies in the field.

During our research we discovered barriers that prevent the introduction of new developments at the national and corporate levels. A comparison of approaches employed by domestic and Finnish heating utility companies makes it possible to make recommendations regarding the development of corporate strategies for innovative development. Special attention is given to breakthrough innovations in cogeneration and trigeneration.

\section{Moscow district heating in brief}

The heat supply system of Russia's capital differs from its counterparts in European cities. It is unique in terms of its scale and is generally comparable to individual EU nations in terms of major characteristics. For example, in 2012 the total length of pipelines in Moscow was 16,323 km and the associated contractual thermal load was $19 \mathrm{GW}^{2}$, which exceeds the corresponding aggregate figures for Finland (roughly 13,600 km and $18.5 \mathrm{GW}$, respectively). MIPC receives gas from a local supplier with a stable distribution system, which reduces the risks of an interruption in supplies and eliminates the need to diversify the types of fuels consumed. The capital's heating companies do not have access to large thermal reservoirs (such as the Baltic Sea for coastal Scandinavian cities or the Pacific Ocean for certain US states) which complicates the creation of certain systems, e.g. free cooling [Euroheat \& Power, 2006; State of Hawaii, 2002] based on seawater. ${ }^{3}$ Finally, the basic source of energy in Moscow is natural gas, which is relatively clean from an environmental point of view.

\footnotetext{
1 Note that the magnitude of this indicator is determined by more than heat suppliers' activities. Considerable energy losses in Russia are due to the inefficient thermal insulation of buildings.

2 Hereinafter, information about MIPC is presented based on annual reports [MIPC, 2005, 2006, 2007, 2008, 2009, 2010, 2011a, 2012].

3 However, there are also other free cooling technologies. For example, see [Baggini, Sumper, 2012; Wu, 2010].
} 
These circumstances sideline potential innovative projects related to diversifying the fuel mix, that are of immediate interest to European heat utilities: the use of boilers fueled by waste from the timber industry, technologies to reduce carbon emissions from thermal power plants, the construction of automatic coal storage facilities, reduction (or the complete elimination) of ash dumping areas, etc. These trends are not high-priority for Moscow's heating industry. Top priority is given to improving reliability and energy efficiency, and developing the information technology (IT) infrastructure. These innovation initiatives are chiefly aimed at testing new pipelines and types of thermal insulation and surfactants [MIPC, 2013a; RosTeplo.Ru, 2010; Startbase, 2014], and introducing variablefrequency drives (VFD) and their analogues [RosTeplo.Ru, 2010]. However, implementation of these technological solutions lags behind other countries. In particular, surfactants have already been used in foreign pipelines systems for nearly 20 years [Pollert et al., 1994], while plastic pipelines have been used since the mid-1980s [KWH Pipe, 2006]. State-of-the-art VFDs are an energyefficient, but very common, flow control technology [Herman, 2009; Petchers, 2003; Bloetscher, 2011]. Such solutions provide gradual quantitative changes that may be viewed as evolutionary innovations at the enterprise level.

There are, however, potential breakthrough innovations related to the combined production of different types of energy which may transform Moscow's energy market radically and of fset its considerable disadvantage - a low capacity factor. This is a typical problem for boiler plants (Figure 1). The summer-time capacity factors are extremely low because a typical boiler plant produces only one type of energy - heat. Hot water supply, which keeps the capacity factor from dropping to zero, does not provide a significant load for the equipment. Evidence confirms $s^{4}$ that increasing a capacity factor is a significant resource in energy sector. It is known that mono-generation, be it electricity or heat generation, is less productive than combined generation of several types of energy [Andrews et al., 2012; Inter RAO UES, 2013; European Commission, 2002; DHC+ Technology Platform, 2009]. Moreover, the transition to combined energy production may contribute to an increased capacity factor. MIPC has two opportunities in this area: expansion of electricity production and production of cooling. The latter would be a breakthrough innovation for the capital's energy industry.

\section{Figure 1. MIPC's capacity factor in winter and summer months (\%)}

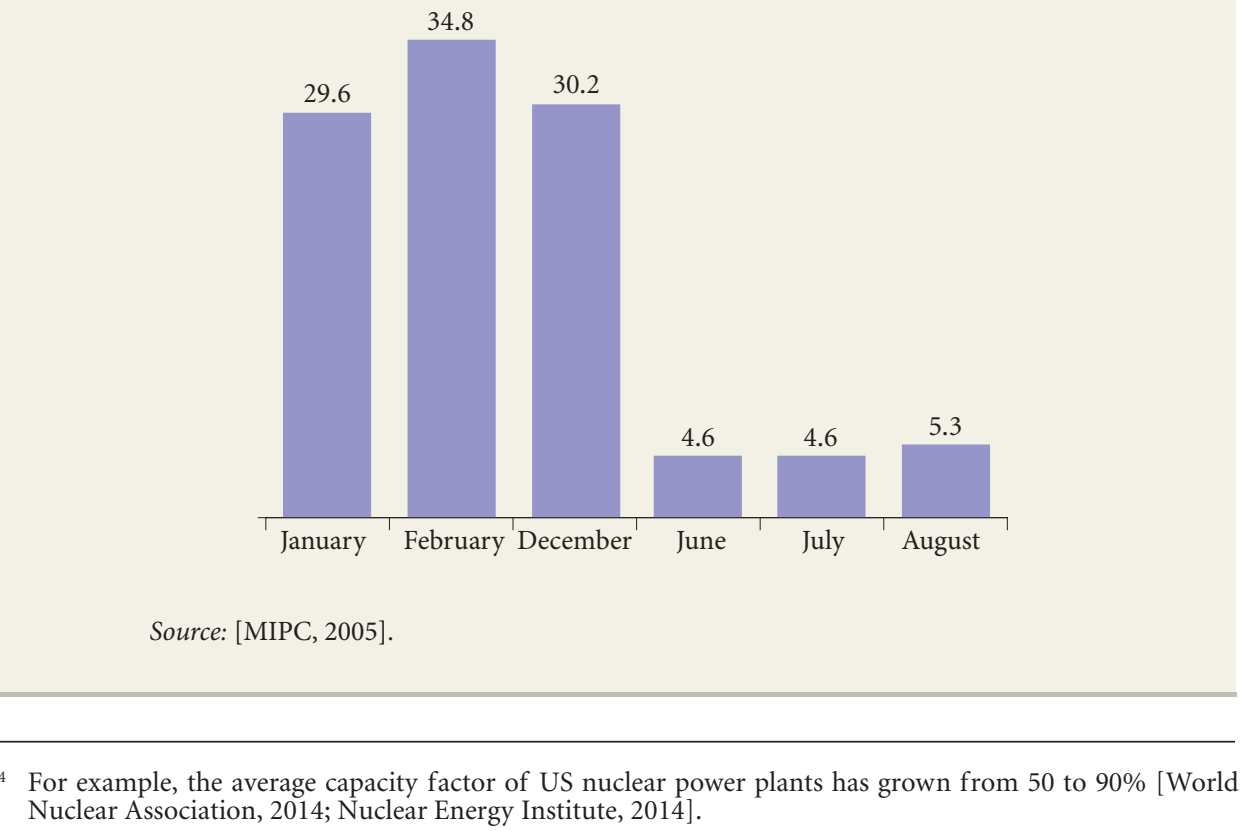


To a certain extent the technological lag is caused by the preceding managerial practices and strategies adopted in Moscow's district heating system. In recent years it has been reorganized repeatedly: multiple changes have been made to the structure and number of enterprises, their functions, internal business processes, and the forms of interaction between them (Figure 2). Before 2004, state unitary enterprises were directly responsible for supplying heat to customers through the operation of heating stations and the separate heat distribution systems of Mosgorteplo, Mosteploenergo (including district heating stations, and accompanying water networks and heating substations), and Teploremontnaladka (service to over 500 heating substations in northeast Moscow). They did not compete with each other, because customers were divided between the companies depending on their location. Innovative development was hampered by the irregular territorial division of heat districts, inefficient business processes, and delayed payments both from customers and to heat suppliers.

In 2004, to consolidate these assets and improve their efficiency, the Moscow government created MIPC, which assumed the role of municipal heat supplier. ${ }^{5}$ The new entity included unitary enterprises which had been reformed into joint stock companies and become its subsidiaries and business units afterwards. Later, MIPC underwent several more reorganizations during which the number and function of the units changed.

Moscow's main sources of heat are Open Joint Stock Company (OAO) Mosenergo's power plants (in 2004, its principal shareholder was OAO Unified Energy System of Russia, or 'RAO UES Russia'6), which was reorganized in 2005. During the reorganization, more than ten business units were separated

\section{Figure 2. Reorganization of the Moscow district heating companies in 2004-2014}

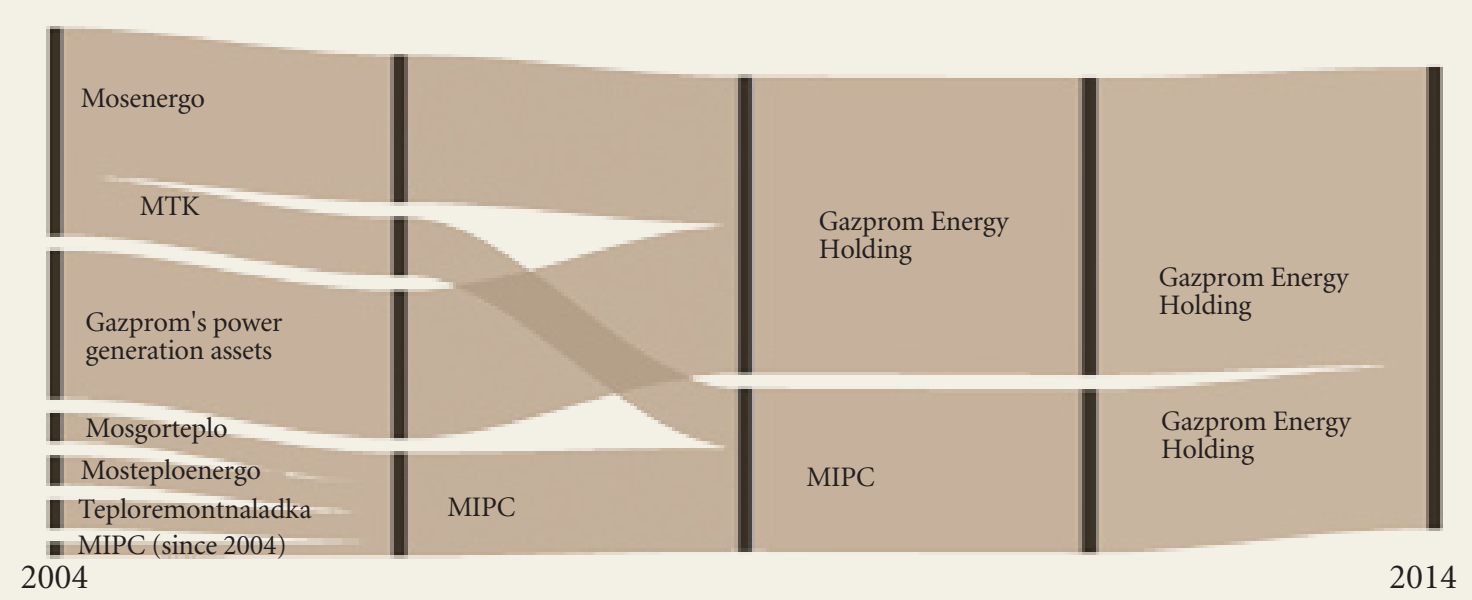

Note: This diagram shows a simplified representation of mergers and acquisitions. It does not depict information about the structure of ownership or organizations' legal status.

Mosenergo is the largest of Russian regional generating companies and the basis of the Moscow energy system. The company comprises 15 power plants for Moscow with an installed electric capacity of $12.3 \mathrm{GW}$ and heat capacity of $35000 \mathrm{Gcal} / \mathrm{h}$, which makes the company the world's largest heat generator. Currently, Mosenergo is a Gazprom Energy Holding subsidiary.

MTK was a Moscow infrastructure company controlling major large-diameter district heating water pipelines used for transporting heat from Mosenergo's power plants to local distribution heating water networks.

Mosgorteplo, Teploremontnalandka, Mosteploenergo were Moscow state unitary enterprises that operated local district heating substations and distribution heating water networks.

(Open Joint Stock Company) Gazprom's power generation assets refer to Gazprom's shares in Russian heat and power generation companies which have been steadily growing over the decade.

Gazprom Energy Holding — operates as a subsidiary of Gazprom (since 2009) and controls its heat and power generating assets such as MOEK, Mosenergo, etc.

Source: Prepared by the authors.

Order of the Government of Moscow 'On the Creation of Open Joint Stock Company Moskovskaya Obedinennaya Energenticheskaya Kompaniya' (including subsequent changes) no 2261-RP, dated November 11, 2004.

6 RAO UES of Russia was a national energy monopoly controlling more than two thirds of Russia's electric power capacity and most of electric transmission grids in Russia. The company was reorganized in $2006-$ 2008 when its subsidiaries were spun off into separate generating companies. 
from Mosenergo, becoming independent companies. One of them was OAO Moskovskaya Teplosetevaya Kompaniya (Open Joint Stock Company Moscow District Heating Network Company, MTK), which controlled the city's main heating water pipelines. The separation of assets made it possible to split competitive businesses from the monopolistic and divide profitable and loss-making assets.In 2007, the capital's government acquired a controlling stake in MTK. Then the government initiated a merger between MTK and MIPC, which was completed in October 2012. The merger did not eliminate the challenges that had existed in heat supply: the imbalances between seasonal fluctuations of the heat load (and the wholesale heat purchased from Mosenergo), the fixed size of the payment received from customers, and the resulting regular cash deficiency for a long time. Correcting the accumulated problems took nearly a decade.

\section{Barriers for innovative activities Low labour productivity}

Insufficient productivity impedes innovative activities because introducing new services based on costly and outdated business processes and service technologies decreases innovations' potential profitability. Given the high discount rates and the inability to introduce inexpensive technologies (for example, free cooling), innovation projects that succeeded abroad in terms of net present value (NPV) could prove to be loss-making in the Russian energy industry. Discount rates associated with the cost of capital for companies depend on the state of the financial markets. Like the lack of access to free thermal reservoirs, this is an external factor that an enterprise is unable to influence. However, an enterprise can improve the efficiency of its operations through technological and managerial innovations.

Many researchers have noted the connection between labour productivity and innovative activities. For example, Philip Cooke asserts that the latter is the primary factor in increasing productivity [Cooke, 2012], while Peter Brödner points out the correlation between a deceleration of growth in productivity and a reduction in innovative activities in Germany [Brödner, 2011]. Studying investments in employees' key skills during a period of crisis, Lidia Garcia Zambrano and her colleagues have also demonstrated a connection between pioneering activities and productivity [García-Zambrano et al., 2014]. In their research on the management of a high-tech company, Roman Boutellier and Mareike Heinzen use labour productivity as one of the characteristics of innovative activities [Boutellier, Heinzen, 2014]. Sorin Krammer evaluates innovative policy by looking at employees' skills and productivity [Krammer, 2009]. Francesco Bogliacino and Mario Pianta, relying on the results of company innovation surveys in EU countries (Community Innovation Surveys, CIS), identified the relationship between the quality of innovative activities and labour productivity [Bogliacino, Pianta, 2009]. However, increasing productivity based on innovations requires a modern overall technological foundation, because low-tech enterprises usually lag behind high-tech enterprises [Kirner et al., 2009] in terms of the effectiveness of their innovative activities.

We compare the labour productivity of several Russian and Finnish energy companies, taking output-labour indicators - the ratio of annual energy sales (GW·h) to the number of employees - as our criteria. To do this, we formed several groups of companies with comparable generation, transmission/distribution and sales indicators. We created three groups of companies:

A. Heat and electric power transmission/distribution systems including heat and electricity sales - the Finnish company Turku Energia and the Russian MIPC / MOESK total staff and sales (green). 
B. Combined generation of heat and power (combined heat and power, CHP), heat and electric power transmission/distribution systems, including heat and electricity sales - Finnish companies Turku District Energy Ltd. ${ }^{7}$ and Turku Energia, and Russian companies Mosenergo, MIPC, and MOESK (blue); Helsingin Energia's data are also provided for comparison.

C. Combined generation of heat and electric power - Mosenergo and Turku District Energy Ltd. (yellow).

It is not possible to achieve a complete match for these groups because of the scale effect and differing distribution of assets. MIPC is a wholesale reseller of heat for Mosenergo ( $67.7 \%$ of the annual heat production by the latter in 2012); and the remaining 32.3\% is supplied to retail customers. In 2012, Mosenergo's heat sales amounted to $6.8663 \cdot 10^{7} \mathrm{Gcal}$, while MIPC's own heat production was $2.4699 \cdot 10^{7} \mathrm{Gcal}$. However, the approximate match makes a qualitative comparison possible.

The data in Table 1 indicates that average labour productivity in the Moscow energy industry is noticeably lower than it is at Turku: by roughly a factor of 2.5-3 for groups A and B. MIPC's employee headcount does not fit the volumes of heat sales, considering that most (about 75\%) of the heat is purchased from Mosenergo. MOESK looks somewhat better. But in this case Turku Energia, which serves two types of transmission and distribution systems (electric power and heat) has demonstrated approximately the same productivity $(\mathrm{E} / \mathrm{P})$ as MOESK, which only operates electric power transmission and distribution systems. Moreover, total productivity at Turku Energia $((\mathrm{Q}+\mathrm{E}) / \mathrm{P})$ is more than twice that of MOESK (E/P). Only Mosenergo is approximately equal to Turku District Energy Ltd (group B).

A cause of the Russian enterprises' considerable lag in labour productivity is technological inefficiency: a low level of automation, mostly manual labour when repairing and maintaining sources and distribution systems, excessive capacity redundancy, and an insufficiently developed IT infrastructure. Eliminating these shortcomings requires a basic set of methodological tools that can be taken from the lean production model. ${ }^{8}$ Despite requiring significant labour and

\begin{tabular}{|c|c|c|c|}
\hline \multicolumn{4}{|c|}{$\begin{array}{l}\text { Table 1. Labour productivity in the production, transmission, and } \\
\text { distribution of heat }(Q) \text { and electricity (E) (GW } h / \text { person) }\end{array}$} \\
\hline & $\begin{array}{l}\mathrm{Q} / \mathrm{P} \\
(G W \cdot h / \\
\text { person })\end{array}$ & $\begin{array}{l}\mathrm{E} / \mathrm{P} \\
(G W \cdot h / \\
\text { person })\end{array}$ & $\begin{array}{l}(\mathrm{Q}+\mathrm{E}) / \mathrm{P} \\
(G W \cdot h / \\
\text { person) }\end{array}$ \\
\hline Turku Energia (2013) & 6.52 & 5.50 & 12.02 \\
\hline Turku District Energy Ltd & 12.26 & 6.25 & 18.51 \\
\hline Turku Energia - Turku District Energy Ltd & 5.55 & 3.59 & 9.15 \\
\hline Helsigin Energia (2012) & 5.39 & 5.25 & 10.64 \\
\hline $\operatorname{MIPC}(2012)$ & 3.25 & - & - \\
\hline Mosenergo (2012) & 9.80 & 8.07 & 17.87 \\
\hline MOESK (2012) & - & 5.16 & - \\
\hline MIPC - MOESK & - & - & 4.01 \\
\hline MIPC - MOESK - Mosenergo & - & - & 4.02 \\
\hline
\end{tabular}

Note: P - employee headcount, Q — annual heat sales $(G W \cdot h), \mathrm{E}$ - annual electricity sales $(G W \cdot h)$. The closest analogue to MIPC is Turku Energia (highlighted by orange).

Source: The authors' calculations based on the publicly available materials of the companies mentioned in the table.

For Turku District Energy Ltd., the heat capacity supplied to industrial customers in Naantali and cooling production of roughly $25 \mathrm{GW} \cdot \mathrm{h}$ are also considered.

8 Methods to model and optimize the operations of technology, industrial, and power companies are described extensively in the literature [Henriques et al., 2014; Curry, Feldman, 2011; Bangert, 2012; de Souza, 2012; O’Kelly, 2013; Blank, 2012]. 
time, optimization may result in improved efficiency and innovative potential. This process has begun at MIPC [Production Management, 2013, 2014; M24.ru, 2013] but so far only concerns some particular operations. It can be considered innovative to an extent because it implies the adoption of the world's best practices used to define optimal operating procedures.

\section{Barriers for long-term planning}

An effective strategy for fostering innovations cannot be separated from the company's overall development strategy [DeSai, 2013]. Setting goals for innovation policy should rely on the corporate strategy and the long-term financial policy.

The Moscow heating industry's development strategy was created over an extended period of time under the influence of several executive bodies - the Government of Moscow, RAO UES, and most recently, under the state-owned energy giant Gazprom. ${ }^{9}$ Each of them implemented their own action plans. The interplay between them entailed adjustments to MIPC's corporate strategy. Thus, it is promising for the company to enter the electricity market, which creates an opportunity to start combined heat and power production using new equipment such as combined-cycle units. To develop power generation, MIPC Generatsiya (MIPC Generation) was created in 2008 as a subsidiary of MIPC. Its assigned task was to achieve a 9\% share of Moscow's power generation market, which required building $1.5 \mathrm{GW}$ of generating capacity [Krivoshapka, 2008]. In the same year, OAO Mosgorenergo passed into the control of MIPC [Mosgorenergo, 2014]. However, in 2012 MIPC's power generation remained at approximately $193 \mathrm{MW}$ [MIPC, 2012], which makes it possible to assume that the expansion strategy was cancelled.

The deployment of 1.5 GW capacity at 14 of MIPC's stations would be the basis for small-scale distributed generation in comparison with Mosenergo's major thermal power plants, which have a larger capacity. On the other hand, the construction and modernization of district and area heat stations in the 1990s and 2000s included the installation and repair of water boilers. Obviously, gas turbines can be purchased and installed independently, but this would be a separate production of heat and power, which does not possess the advantages of combined generation. The possibility of simultaneously modernizing boilers to recover heat from the turbines' exhaust, which would increase the project's cost, could be explored. In this regard, the attempt to change the strategy proved difficult due to the decisions that had been previously adopted as part of a different strategy. Such inconsistency (short-termism) is a common corporate management problem [Barton, Wiseman, 2013; Kappel, 1960] that affects both innovative development [Tidd et al., 2005; Johnson et al., 2008] and the general long-term perspective [McLaney, 2009].

The difficulties of planning for the distant future are illustrated in the chart (Figure 3), which demonstrates that in 2011 MIPC lost 14\% of its associated contractual thermal load. The twofold increase in MIPC's heating capacity reserve in 2011 roughly corresponds to the decrease in the load. This drop could presumably be the result of the reassessment of customer characteristics based on new power consumption standards. ${ }^{10}$ In this case, the 'virtual' changes are rather an indication of the degree of uncertainty concerning the city's energy balance than evidence of improved energy efficiency in Moscow.

\section{Lack of Intrapreneurs}

Research has shown that district cooling is economically justified [Shimoda et al., 2006; Chow et al., 2004; Lozano et al., 2010; Deng et al., 2011]. It enables

9 Gazprom's core business is associated with the extraction and sale of gas, which potentially conflicts with the need to improve the energy efficiency of heat supply.

${ }^{10}$ Order of the Ministry of Regional Development 'On Confirmation of the Rules to Establish and Change (Review) Thermal Loads' no 610, dated 28.12.2009. 
Figure. 3. Associated contractual load (left vertical axis, Gcal/h), reserve capacity (right vertical axis, Gcal/h)

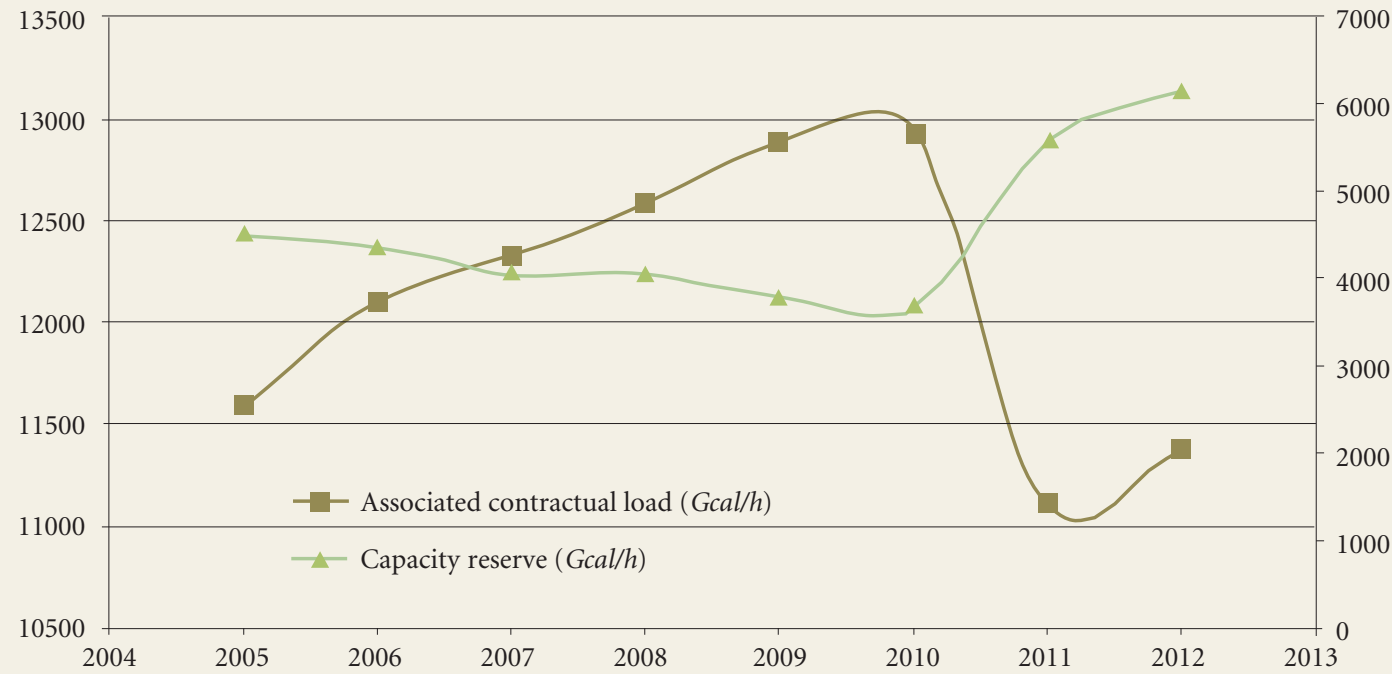

Source: MIPC's annual reports for 2005-2012.

heat which would be otherwise lost to be used for cooling. District cooling can potentially be a breakthrough innovation for the domestic heating industry for several reasons:

- Such systems, including sources of cooling, cold water network (there are water supply systems, but in this case water is not a cooling medium and the conditions are different), and residential equipment have not yet been developed in Russia; there are no long-standing practices for selecting and maintaining equipment, no guidelines for feasibility studies, etc.

- Designing district cooling systems represents a complex engineering challenge, involving a switch from the heat delivery control by water temperature variation (which is widely used at present in Russian heating water networks) to the heat delivery control by flow rate variation, the construction of cold water storages integrated into the cooling water network, operating water networks in a different temperature range, different water treatment conditions, etc.

- There may be an opportunity to combine production of electric power, heat, and cooling (trigeneration) and use new methods for unit commitment optimization.

As early as 2010, the Moscow government considered ways to introduce trigeneration [Ivanov, 2010]. Priority was given to centralized generation. Despite the fact that MIPC has indicated its interest in cold supply [MIPC, 2013b; The Presidential Council for Economic Modernization and the Innovative Development of Russia, 2012], construction dates have still not been set.

It is well known that adopting breakthrough innovations is hampered by certain barriers [Ford et al., 2014]. For Russian companies, these barriers are accompanied by problems associated with the specifics of the national and regional economy, and the business environment in particular. For MIPC, unlike other European players, building a centralized cooling supply system is a more difficult organizational and engineering challenge. Unlike the Finnish Helsingin Energia, MIPC does not have sufficient CHP electricity-generating capacity to 
power vapour-compression chillers for a district cooling system. Free cooling can hardly be used in Moscow. For this reason the company will likely be forced to focus on relatively low-efficiency absorption refrigerators or buy electric power for vapour-compression refrigerators, which may be quite expensive.

Such difficulties are frequently resolved through the organization of a new 'start-up' business entity or division (intrapreneurship, corporate new ventures) [Byers et al., 2011]. In this case, the core business is isolated from the risks and there are greater opportunities for innovative pilot projects to be flexibly managed. However, major Russian companies have little experience in organizing such start-ups.

MIPC managers are wary of launching a large-scale district cooling programme. It is telling that Gazprom Promgaz, which developed a detailed plan (approved by MIPC) for supplying heat and gas to the 'New Moscow' ${ }^{11}$ area, makes only one reference to the district cooling system based on trigeneration. The plan states: 'It is planned to unite the generating facilities in new areas with power substations to create a unified consumer power supply system, Energokompleks, with the additional ability to produce cooling (trigeneration), if needed.' [Government of Moscow, 2014].

\section{Subsidies and the lack of competition}

When a company enters a new market with an innovative product or service, the first customers share the risks associated with the early adoption of this product. This is especially true in the energy industry, which requires large-scale investments and thus, switching from one cooling technology to another may be very costly. District cooling is no exception.

The conquest by district heating companies of untapped markets is inhibited by their weak connection with customers and insufficient flexibility in their interactions with them. For example, customers must contact the companies and submit a request for a 'technological conjunction' with the heating water network which may be a time-consuming and laborious process. District cooling is a new field for Russia - no single player in this market is close to even having a local monopoly. Players must prove their competitiveness and fight for customers, but the Moscow district heating companies have not demonstrated their intention of doing so. Yet interaction with customers itself could benefit from innovations already tested in other industries or abroad [Mattsson, 2008] in areas such as organizational flexibility, customer relations strategy, remote services, etc. [Nandakumar et al., 2014; Edward, Sushil, 2013; Eapen, 2009; Peppers, Rogers, 2011; Eid, 2013]. However, development in these areas is slowed by several circumstances.

Customer relationship management is naturally driven by the competitive pressure and a customer's decision to buy from the company which finally generates its revenue. In Russian district heating this connection is distorted. Unlike European practice, Russian district heating companies are systematically subsidized. ${ }^{12}$ This condition is determined by Federal Law 'On the Heat Supply' no 190-FZ, dated 27.07.2010, which spells out the principles for regulating tariffs. Article 7 of that law states that the tariffs should be affordable. Article 7 also requires local governments to ensure sufficient financing for heating systems. Article 3 stipulates the foundations of the state policy, including the develop-

${ }^{11}$ The 'New Moscow' is a colloquial name of a group of newly established Moscow districts.

${ }_{12}$ To cite just a few examples, we will mention the Decree of Kursk Regional Administration 'On the Process for Providing Subsidies to Organizations Providing Heat, Cold and Hot Water, Water Disposal, and Solid Household Waste Recycling (Disposal) Services, to Compensate for a Portion of Income Not Received Due to the Application of State Regulated Prices (Tariffs) when Rendering Services to the Public' no 1140-pa, dated 26.12.2012; Decrees of the Government of Moscow 'On Confirmation of Prices, Rates, and Tariffs for Housing and Public Utility Services for the Public' no 1038-PP, dated 30.11.2010 (revised 14.12.2010) and 'On Confirmation of Prices, Rates, and Tariffs for Housing and Public Utility Services for the Public for 2014' no 748-PP, 26.12.2013. 
ment of centralized heating supply, balancing the economic interests of heat suppliers and customers, and providing consistent and non-discriminatory conditions for entrepreneurial activities.

Subsidization and monopolization distort the incentives, which are supposed to reflect the actual costs of heat production and distribution. Competitors who do not receive this support face increased price pressure. As a result, the state is accumulating inefficiency, hampering partnership between service providers and customers, and thereby incurring systemic risks. Indeed, regulation in the energy industry is itself a potential risk [Peterson, Augustine, 2003; Sweeney, 2002].

In Finland, priority is given to promoting competition: a centralized district heating operator is one of the market players, with whom local heat producers may compete [Finnish Energy Industries, 2013]. Thus, in Finland there is no counterpart to the aforementioned Russian law 'On the Heat Supply'. In Russian practice, the centralized model is emphasized, which complicates the district heating's transition to market principles. Certain restrictions and regulatory documents have been imposed. For example, the 'Rules for the Organization of the Heat Supply System in the Russian Federation' (Approved by Order of the Government of the Russian Federation no 808, dated 08.08.2012) stipulate the procedure by which the status of sole heat supplier is conferred. A sole heat supplier may revoke the contract cancellation option for a customer if the supplier unilaterally considers that the corresponding disconnection in the water network may have a negative impact on other customers (paragraph 32 of the Rules).

In 'New' Moscow, as well as in other regions, given the amount of heat losses in water networks and the depreciated equipment, versatile solutions based on modern condensing boilers may prove efficient, at least when competing with boiler plants. However, paragraph 2.3 of the Government of Moscow Decree no 1508-PP 'On the City of Moscow's Heat Supply Plan for the Period up until 2020 with Identification of Two Stages in 2010 and 2015' states that 'decentralized heat supply sources shall be used in exceptional cases approved by the City of Moscow's Fuel and Energy Department, or as emergency or backup sources.' ${ }^{13}$

Russian district heating systems are less efficient technologically and economically than their best foreign counterparts. For this reason, local small-capacity heating sources based on highly efficient cogeneration plants seem entirely commercially viable as innovative solutions [Pehnt et al., 2006; Parker, 2009; Pilatowsky et al., 2011; Praetorius et al., 2012]. However, artificial administrative prohibitions must be revoked for them to spread. Liberalization of the Russian gas market and incentives for utility companies engaged in small-scale distributed generation of heat and power are capable of making a positive contribution.

\section{Innovation in district heating companies' strategies}

\section{Knowledge management}

The key underlying element of technological innovations is knowledge management. To this day, a significant portion of Russian infrastructure companies' documents - from thermal and hydraulic diagrams to information about equipment's operating modes - remains undigitized and stored on paper. Even if some information has been digitized, there may be no standard procedure for accessing it. Information exchange is not only problematic in IT but also in organizational dynamics: collaboration between specialists and managers of different levels, especially if they are not direct subordinates, has not been developed or formalized. Similar problems persist in many large Russian en-

13 Available at: https://www.mos.ru/documents/index.php?id_4=118398, accessed 17.06.2014. 
terprises - tech companies, industrial and infrastructure companies, utility enterprises, and others.

The development of knowledge management systems at companies focused on innovations must incorporate procedures widely accepted in the scientific community: peer review, collective decision-making and appraisal, etc. There are definitely not enough seminars, conferences, and workshops. Of course, there must be a reasonable balance between transparency and business interests (including protecting intellectual property). However, at present a closed mindset and non-transparency dominate in this field in Russia.

Finally, the transition to market principles in an area as complex as the energy industry requires consistent optimization of production facilities and distribution systems using appropriate analytical methods, which is impossible without consistent knowledge management programmes. An example of such an optimization is the calculation of the optimal load allocation (unit commitment problem) [Wood et al., 2013; Tagare, 2011; Catalao, 2012; Soliman, Mantawy, 2012]. Such a calculation is also relevant to thermal loads [Sakawa et al., 2002]. Load allocation in Russia's district heating has not been analyzed at this level, even though it has significant innovative potential.

\section{Collaborative networks as the basis for technological innovations}

The way innovations are developed and adopted in enterprises is changing fundamentally. They are starting to engage customers in the search for innovations. The $\mathrm{R} \& \mathrm{D}$ process is becoming more diversified and more specialized [Chesbrough, 2003]. At present, it is impossible to gather all the required specialists in one organization because they are affiliated with many organizations and there is often no need for their full-time labour. Many innovative companies are becoming open: consequently, they have a growing number of ties to external partners and contractors and pioneering activities are becoming interconnected.

General Electric (GE) is an example of this trend. For a decade it has allocated an average of approximately 4.3 billion USD to research and development (R\&D) per year, which exceeds the average annual budget for the Russian Academy of Sciences for the same period. GE initiated an open innovation program [Bingham, Spradlin, 2011; Möslein, 2014]. It is aimed at technological crowdsourcing and mobilizing external contractors who specialize in key technologies such as $3 \mathrm{D}$-printing.

The term 'network' is not coincidental. The interactions of $R \& D$ participants are similar in structure to traditional information networks [Scherngell, 2013; Prahalad, Krishnan, 2008; Tidd et al., 2005]. Scholars today are vigorously studying innovative network processes [Grosfeld, Roelandt, 2008; Prause, Thurner, 2014]. According to Nabil Sakkab, a senior vice president at Procter \& Gamble ( $P \& G)$, the future of corporate R\&D is network structures for collaborative work, uniting $99 \%$ of researchers [Tidd et al., 2005]. P\&G has a research budget comparable to GE's, and one of its most important principles is to 'Connect and Develop.' Similarly, Bosch leader Franz Fehrerback is confident that his company 'will expand its work in research networks with other firms' [Dutta et al., 2009].

A 'closed innovation' model was practiced 30-40 years ago by many companies famous for innovative success but nowadays seems obsolete. ${ }^{14}$ Under these conditions, small firms that lack GE's massive R\&D budgets but are trying to implement innovative solutions are essentially left no choice other than to develop their own 'innovation network.' Georg Weiers notes that more and more new

${ }^{14}$ PARC Research Facility (Xerox) is a good example of the 'closed' approach at that time. 
solutions are coming into a company from outside and engineering research is increasingly distributed across collaborative networks. This trend accelerates development speed and reduces risks and expenses which are redistributed across the entire network [Weiers, 2014]. By contrast, by closing the innovation process, a company assumes the corresponding risks. Furthermore, 'external' innovative activities should not preclude internal developments. It has been demonstrated that conducting internal corporate R\&D simplifies the implementation of external innovations [Hervas-Oliver et al., 2011].

In this context, managing distributed developments acquires special importance. People are actively studying these practices abroad [ $M$ hring et al., 2014] but not yet in Russia, especially regarding interactions with foreign partners; that affects the implementation of R\&D.

Another significant factor impacting the efficiency of distributed innovative developments is the ability to engage a large number of experts and consultants companies and individuals - especially for a feasibility study of industrial and technological projects. Developing collaboration with multiple partners at a proper level is a managerial challenge which includes knowledge management and the development of an IT infrastructure. DuPont asserted its global leadership in R\&D due to a distributed network for collaborative scientific and engineering work [Boutellier et al., 2008] while keeping the focus on the distributed IT infrastructure which provides tools for distributed collaborative R\&D teams. It saves financial and time resources because there is no need to reorganize $\mathrm{R} \& \mathrm{D}$ divisions under new programmes. Otherwise, significant expenses would be required to support employees' international mobility.

In Russia, the usual practice is based on the principle of 'doing everything ourselves', which leads to an extreme concentration of research and development activity within a single organization and weak specialization, and few $\mathrm{R} \& \mathrm{D}$ centres, thereby further weakening competition. The current level of competition does not correspond to the amount of financing allocated by companies for innovative development. As a result, market power is shifting from the company to its $\mathrm{R} \& \mathrm{D}$ contractor. Several major corporations are of ten forced to invest in the same limited pool of $\mathrm{R} \& \mathrm{D}$ projects, i.e. in effect they have to compete for a contractor.

The Russian market for innovations is in acute need of competition. In the long run, this problem may be solved through systematic development of scientific organizations and their collaboration with technology companies. Involving foreign innovative firms and applied research centres in Russian innovative projects would bring a quick positive effect.

\section{Conclusions}

Innovations in Russian district heating are chiefly evolutionary or incremental. The innovations are often based on introducing technologies whose effectiveness has been proven through many years of operation abroad. Moving forward with breakthrough solutions, even if they have proven their effectiveness at leading global companies and are supported by federal and regional authorities, encounters significant obstacles in Russia. These obstacles include inflexible corporate management, including when interacting with customers, and inexperience in creating internal corporate startups and managing risks in the early stages of R\&D.

The technological gap results in increased costs when assessing innovative projects' investment attractiveness. Excessive costs are critical for the development of new infrastructure that has significant initial fixed costs, as in the case of district cooling. 
Recommended measures to support the innovative development of district heating can be split into institutional and corporate recommendations. The first group concerns stimulating competition in the heat supply market and creating a stable legal and investment environment. The second group calls for technological modernization, development of long-term corporate strategies that include investment programmes, systematic analysis of the best international practices for innovative development, and the formation of partner networks involving foreign innovative, consulting, and research centres.

The example of Moscow demonstrates that energy companies' strategic development in the past decade was focused primarily on mergers, not innovation. The capital's horizontal mergers of the 2000s and subsequent vertical mergers were performed based on administrative considerations. As a result, business processes and cash flows were largely streamlined but the European level of productivity was not achieved. The creation of a single vertically integrated entity in Moscow's energy industry has limited the ability to develop alternative heating systems. The tariff policy and subsidies in combination with regulatory restrictions on alternative heat supply technologies essentially neutralize the incentives for companies to implement innovation policies. Multiple reorganizations in Moscow's energy sector resulted in the domination of short-term planning, while long-term strategic planning is virtually non-existent.

Experience has shown that centralization does not guarantee simplicity in the interactions between the main entities of Moscow's energy industry. As an example, consider the cash deficiency caused by the seasonal variation in MIPC's thermal load and the particulars of purchasing heating capacity from Mosenergo.

Many large Russian companies tend to follow the 'closed innovation' model where $\mathrm{R} \& \mathrm{D}$ activities are concentrated within an organization. In contrast, the predominant trend demonstrated by the major technological leaders abroad is clearly the opposite. Innovative engineering solutions are developed in broad, of ten international, collaborations which make the development more efficient and less risky

Andrews D., Riekkola A. K., Tzimas E., Serpa J., Carlsson J., Pardo-Garcia N., Papaioannou I. (2012) Background Report on EU-27 District Heating and Cooling: Potentials, Barriers, Best Practice and Measures of Promotion, Brussels: European Commission.

Baggini A., Sumper A. (2012) Electrical energy efficiency, New York: Wiley.

Bangert P. (2012) Optimization for Industrial Problems, Heidelberg, Dordrecht, London, New York: Springer.

Barton D., Wiseman M. (2013) Focusing capital on the long term. Harvard Business Review, January-February, pp. 48-55.

Begalov V. (2013) Aktual'nye voprosy energosberezheniya i povysheniya effektivnosti ispol'zovaniya energoresursov pri razrabotke skhem teplosnabzheniya [Topical issues of energy saving and energy efficiency in the designing district heating infrastructure]. Energosovet, no 3 (28), pp. 77-80.

Bingham A., Spradlin D. (2011) The open innovation marketplace: Creating value in the challenge-driven enterprise, Waltham, MA: InnoCentive Inc.

Blank R. (2012) Cross-Functional Productivity Improvement, London: CRC Press.

Bloetscher F. (2011) Utility Management for Water and Wastewater Operators, Denver, CO: American Water Works Association.

Bogliacino F., Pianta M. (2009) The impact of innovation on labour productivity growth in European industries: Does it depend on firms' competitiveness strategies? (IPTS working paper on corporate R\&D and innovation no 13/2009), Brussels: European Commission.

Boutellier R., Gassmann O., Von Zedtwitz M. (2008) Managing global innovation: Uncovering the secrets of future competitiveness (3rd ed.), Heidelberg, Dordrecht, London, New York: Springer.

Boutellier R., Heinzen M. (2014) Growth Through Innovation: Managing the Technology-Driven Enterprise, Heidelberg, Dordrecht, London, New York: Springer. 
Brödner P. (2011) Innovations Require Conducive Institutions. Enabling Innovation. Innovative Capability - German and International Views (eds. I. Isenhardt, F. Hees, S. Trantow), RWTH Aachen University P.S.J., Springer, pp. 179-183.

Byers L., Dorf R., Nelson A. (2011) Technology Ventures: From Idea to Enterprise, New York: McGraw-Hill.

Catalao J.P.S. (ed.) (2012) Electric Power Systems: Advanced Forecasting Techniques and Optimal Generation Scheduling. London: CRC Press.

Chesbrough H.W. (2003) Open Innovation: The New Imperative for Creating and Profiting from Technology, Boston: Harvard Business School Press.

Chow T.T, Au W.H., Yau R., Cheng V., Chan A., Fong K.F. (2004) Applying district-cooling technology in Hong Kong. Applied Energy, vol. 79, no 3, pp. 275-289.

Cooke P. (2012) Complex Adaptive Innovation Systems Relatedness and Transversality in the Evolving Region, London: Routledge.

Council for Economic Modernisation and Innovative Development (2012) MOEK rassmatrivaet pilotnye proekty trigeneratsii na territorii Skolkovo i 'Moskva-siti' [MIPC examines the trigeneration pilot projects in Skolkovo and 'Moscow City'], 28.12.2012. Available at: http://i-russia.ru/all/articles/16540/, accessed 19.06.2014.

Curry G.L., Feldman R.M. (2011) Manufacturing Systems Modeling and Analysis (2nd ed.), Heidelberg, Dordrecht, London, New York: Springer.

De Souza G.F.M. (ed.) (2012) Thermal Power Plant Performance Analysis, Heidelberg, Dordrecht, London, New York: Springer.

Deng J., Wang R.Z., Han G.Y. (2011) A review of thermally activated cooling technologies for combined cooling, heating and power systems. Progress in Energy and Combustion Science, vol. 37, no 2, pp. 172-203.

DeSai J. (2013) Innovation Engine: Driving Execution for Breakthrough Results, New York: Wiley.

DHC+ Technology Platform (2009) The District Heating and Cooling plus (DHC+) Technology Platform: District Heating \& Cooling - A Vision Towards 2020 - 2030 - 2050, Brussels: DHC+ Technology Platform.

Dutta S., Berger R., Raffel T., Samuels G. (eds.) (2009) Innovating at the Top: How Global CEOs Drive Innovation for Growth and Profit, Roland Berger Strategy Consultants, INSEAD.

Eapen G. (2009) Flexibility: Flexible Companies for the Uncertain World, London: CRC Press.

Edward A., Sushil S. (2013) The Flexible Enterprise, Heidelberg, Dordrecht, London, New York: Springer.

Eid R. (2013) Managing Customer Trust, Satisfaction, and Loyalty through Information Communication Technologies, Hershey, PA: IGI Global. Available at: 10.4018/978-1-4666-3631-6, accessed 19.06.2014.

Euroheat \& Power (2006) District Cooling: Cooling More with Less, May 2006, Brussels: Euroheat \& Power. Available at: http://www.euroheat.org/Admin/Public/DWSDownload.aspx?File=/Files/Filer/documents/positionpapers/District_ Cooling/EHPCoolingMoreWithLessS.pdf, accessed 19.06.2014.

European Commission (2002) The Act on the Conservation, Modernization and Development of Combined Heat and Power, April 1, 2002, Brussels: European Commission.

Finnish Energy Industries (2013) Strategy for the district heating sector, Helsinki: Finnish Energy Industries. Available at: http://energia.fi/sites/default/files/kaukol_strategia_eng_2410.pdf, accessed 19.06.2014.

Ford S., Ferriani S., Probert D. (2014) Overcoming the innovation barrier: A search-selection model of breakthrough innovation in large firms. Strategy and Communication for Innovation (eds. N. Pfeffermann, T. Minshall, L. Mortara), Heidelberg, Dordrecht, London, New York: Springer, pp. 41-63.

García-Zambrano L., Rodríguez-Castellanos A., García-Merino J.D. (2014) Proactive Management of Core Competencies, Innovation and Business Performance in a Period of Crisis: The Case of Spain. Entrepreneurship, Innovation and Economic: Lessons for Research, Policy and Practice (eds. K. Rüdiger, M. Peris-Ortiz, A. BlancoGonzález), Heidelberg, Dordrecht, London, New York: Springer, pp. 59-68.

Government of Moscow (2014) O trebovaniyakh $k$ skhemam teplosnabzheniya, poryadku ikh razrabotki i utverzhdeniya (etap 1, tom 1.4, kniga 1) [On the requirements for heating schemes, the order of their development and approval (step 1, Volume 1.4, Book 1)]. Available at: http://depteh.mos.ru/legislation/projects/1070692/, accessed 19.06.2014.

Grosfeld T., Roelandt T. (2008) Logika otkrytykh innovatsii: sozdanie stoimosti putem ob"edineniya setei i znanii [The Logic of Open Innovation: Making Value by Connecting Networks and Knowledge]. Foresight-Russia, vol. 2, no 1, pp. 24-29.

Henriques E., Pecas P., Silva A. (eds.) (2014) Technology and Manufacturing Process Selection: The Product Life Cycle Perspective, Heidelberg, Dordrecht, London, New York: Springer.

Herman S.L. (2009) Industrial Motor Control (6th ed.), Delmar Cengage Learning.

Hervas-Oliver J.-L., Garrigos J. A., Gil-Pechuan I. (2011) Making sense of innovation by R\&D and non-R\&D innovators in low technology contexts: A forgotten lesson for policymakers. Technovation, vol. 31, no 9, pp. 427-446.

IFC, World Bank (2008) Energy Efficiency in Russia: Untapped Reserves, Moscow: International Finance Corporation, World Bank.

Inter RAO UES (2013) Ostat'sya s teplom [Staying with the heat]. Energiya bez granits, no 4 (23), September 2013, pp. 10-15. Available at: http://www.interrao.ru/upload/iblock/b66/Inter_RAO_4(23)_2013.pdf, accessed 19.06.2014.

Ivanov A. (2010) Energoobepechenie Moskvy: zadachi i napravleniya razvitiya [Energy supply in Moscow: Challenges and directions for the development]. Energopolis, 20.05.2010. Available at: http://energypolis.ru/portal/2010/391yenergoobespechenie-moskvy-zadachi-i-napravleniya.html, accessed 19.06.2014. 
Johnson G., Scholes K., Whittington R. (2008) Exploring Corporate Strategy (8th ed.), Essex: Prentice Hall, Person Education Ltd.

Kappel F. (1960) Vitality: In a Business Enterprise, New York: McGraw-Hill Education.

Kirner E., Kinkel S., Jaeger A. (2009) Innovation paths and the innovation performance of low-technology firms An empirical analysis of German industry. Research Policy, vol. 38, no 3, pp. 447-458.

Kozhukhovskii I. (2013) Obzor energeticheskikh rynkov Rossii [Review of Russian energy markets]. Available at: http://iiab. hse.ru/news/103218273.html, accessed 19.06.2014.

Krammer S.M.S. (2009) Drivers of national innovation in transition: Evidence from a panel of Eastern European countries. Research Policy, vol. 38, no 5, pp. 845-860.

Krivoshapka I. (2008) Teplosnabzhenie bez problem - stolichnyi opyt [Heating without problems - Evidence from the capital]. Energetika i promyshlennost' Rossii, no 10 (102).

KWH Pipe (2006) Development of KWH Technology. Pipe world - The KWH pipe customer journal, no 1, pp. 6-10.

Lozano M.A., Ramos J.C., Serra L.M. (2010) Cost optimization of the design of CHCP (combined heat, cooling and power) systems under legal constraints. Energy, vol. 35, no 2, pp. 794-805.

M24.ru (2013) 'MOEK' sekonomit 300 millionov na novykh tekhnologiyakh [Moscow Integrated Power Company will save 300 million with new technologies], 15.03.2013. Available at: http://www.m24.ru/news/4959, accessed 19.06.2014.

Mattsson J. (2008) Customer Relationship Management (CRM) as innovation: Taking care of the right customers. Innovation and the Creative Process: Towards Innovation with Care (ed. L. Fuglsang), Cheltenham: Edward Elgar, pp. 48-56.

McLaney E. (2009) Business Finance: Theory and Practice (8th ed.), Essex: Person Education Ltd.

Merrow E.W. (2011) Industrial Megaprojects: Concepts, Strategies, and Practices for Success, New York: Wiley.

Ministry of Energy (2013) Politika v teplosnabzhenii [Policy in Heating], Moscow: Ministry of Energy of the Russian Federation. Available at: http://minenergo.gov.ru/upload/iblock/2a1/2a186182f1ce1484577da18d98938694.pdf, accessed 19.06.2014.

MIPC (2005) Godovoi otchet [Annual Report], Moscow: Moscow Integrated Power Company. Available at: http://www. oaomoek.ru/ru/investor/reports.html, accessed 19.06.2014.

MIPC (2006) Godovoi otchet [Annual Report], Moscow: Moscow Integrated Power Company. Available at: http://www. oaomoek.ru/ru/investor/reports.html, accessed 19.06.2014.

MIPC (2007) Godovoi otchet [Annual Report], Moscow: Moscow Integrated Power Company. Available at: http://www. oaomoek.ru/ru/investor/reports.html, accessed 19.06.2014.

MIPC (2008) Godovoi otchet [Annual Report], Moscow: Moscow Integrated Power Company. Available at: http://www. oaomoek.ru/ru/investor/reports.html, accessed 19.06.2014.

MIPC (2009) Godovoi otchet [Annual Report], Moscow: Moscow Integrated Power Company. Available at: http://www. oaomoek.ru/ru/investor/reports.html, accessed 19.06.2014.

MIPC (2010) Godovoi otchet [Annual Report], Moscow: Moscow Integrated Power Company. Available at: http://www. oaomoek.ru/ru/investor/reports.html, accessed 19.06.2014.

MIPC (2011a) Godovoi otchet [Annual Report], Moscow: Moscow Integrated Power Company. Available at: http://www. oaomoek.ru/ru/investor/reports.html, accessed 19.06.2014.

MIPC (2011b) Prakticheskii opyt MOEK vyzval interes na forume "Innovatsii. Modernizatsiya. Energoeffektivnost" [MIPC experience sparked interest in the forum on Innovation, Modernisation and Energy Efficiency]. Available at: http://www. oaomoek.ru/ru/press-center/news-releases/news-archive-2011/698-moek-news2011-09-30.html, accessed 19.06.2014.

MIPC (2012) Godovoi otchet [Annual Report], Moscow: Moscow Integrated Power Company. Available at: http://www. oaomoek.ru/ru/_downloads/investor/otchet/god-otchet_moek_2012_full.pdf, accessed 06/19/2014.

MIPC (2013a) MOEK vnedryaet innovatsii na ob"ektakh teplosetevoi infrastruktury [MIPC implements innovations in thermal grid infrastructure], 15.03.2013. Available at: http://www.oaomoek.ru/ru/press-center/news-releases/news2013/928-moek-vnedryaet-innovacii.html, accessed 16.06.2014.

MIPC (2013b) OAO «MOEK» predlagaet uslugi po khladosnabzheniyu i vnedryaet trigeneratsiyu [MIPC offers services on cold supply and implementing trigeneration], 15.04.2013. Available at: http://www.oaomoek.ru/ru/press-center/newsreleases/news-2013/971-trigeneraciya-moek.html, accessed 19.06.2014.

Möhring M.M. (2014) Innovation in a High Technology B2B Context: Exploring Supply Networks, Processes and Management, Heidelberg, Dordrecht, London, New York: Springer.

Mosgorenergo (2014) «Mosgorenergo» opublikovalo itogi deyatel'nosti za 2013 god ["Mosgorenergo" published results of operations for 2013], 31.01.2014. Available at: http://www.mosgorenergo.ru/press-center/market-news/244/, accessed 19.06.2014.

Möslein K.M. (2014) Open Innovation: Strategic Options, Actors, Tools and Tensions. Strategy and Communication for Innovation (eds. N. Pfeffermann, T. Minshall, L. Mortara), Heidelberg, Dordrecht, London, New York: Springer, pp. 27-40.

Nandakumar M.K., Jharkharia S., Nair A.S. (2014) Organisational Flexibility and Competitiveness, Heidelberg, Dordrecht, London, New York: Springer. 
Nuclear Energy Institute (2014) US Nuclear Capacity Factors. Available at: http://www.nei.org/Knowledge-Center/NuclearStatistics/US-Nuclear-Power-Plants/US-Nuclear-Capacity-Factors, accessed 19.06.2014.

O'Kelly P. (2013) Computer Simulation of Thermal Plant Operations, Heidelberg, Dordrecht, London, New York: Springer.

Parker D. (2009) Microgeneration: Low energy strategies for larger buildings, Elsevier.

Pehnt M., Cames M., Fischer C., Praetorius B., Schneider L., Schumacher K., Voß J.-P. (2006) Micro Cogeneration Towards Decentralized Energy Systems, Heidelberg, Dordrecht, London, New York: Springer.

Peppers D., Rogers M. (2011) Managing Customer Relationships: A Strategic Framework, New York: Wiley.

Petchers N. (2003) Combined Heating, Cooling \& Power Handbook: Technologies \& Applications. An Integrated Approach to Energy Resource Optimization, Lilburn, Georgia: The Fairmont Press.

Peterson S., Augustine C. (2003) Regulatory Failure in the California Electricity Crisis. The Electricity Journal, vol. 16, no 7, pp. 56-64.

Pilatowsky I., Romero Rosenberg J., Isaza C.A., Gamboa S.A. (2011) Cogeneration Fuel Cell-Sorption Air Conditioning Systems. Heidelberg, Dordrecht, London, New York: Springer.

Pollert J., Zakin J.L., Myska J., Kratochvil K. (1994) Use of friction reducing additives in district heating system field test at Kladno-Krocehlavy. Proceedings of the International District Heating and Cooling Conference, Prague, vol. 85, pp. 141-156.

Praetorius B., Martiskainen M., Sauter R., Watson J. (2012) Microgeneration in the UK and Germany from a Technological Innovation Systems Perspective. Sustainability Innovations in the Electricity Sector (eds. D. Jansen, K. Ostertag, R. Walz), Heidelberg, Dordrecht, London, New York: Springer, pp. 117-140.

Prahalad C.K., Krishnan M.S. (2008) The New Age of Innovation: Driving Cocreated Value Through Global Networks, New York: McGraw Hill Education.

Prause G., Thurner T. (2014) Soobshchestva potrebitelei — draivery otkrytykh innovatsii [User Communities - Drivers for Open Innovation]. Foresight-Russia, vol. 8, no 1, pp. 24-32.

Production Management (2013) Proekt STEP: shagi MOEK v budushchee [Project STEP: MIPC steps into the future], 12.03.2013. Available at: http://www.up-pro.ru/library/production_management/lean/svetlov-moek.html, accessed 19.06.2014.

Production Management (2014) Protsessnoe upravlenie v MOEK v ramkakh proekta 'VEGA' [Process management in MIPC project 'VEGA'], 11.06.2014. Available at: http://www.up-pro.ru/library/information_systems/management/processnoemoek.html, accessed 19.06.2014.

RosTeplo.Ru (2010) V OAO «MOEK» vnedryayutsya innovatsionnye tekhnologii [MIPC implements innovation techniques], 08.10.2010. Available at: http://www.rosteplo.ru/news.php?zag=1286518651, accessed 19.06.2014.

Sakawa M., Kato K., Ushiro S. (2002) Operational planning of district heating and cooling plants through genetic algorithms for mixed 0-1 linear programming. European Journal of Operational Research, vol. 137, no 3, pp. 677-687.

Scherngell T. (ed.) (2013) The Geography of Networks and R\&D Collaborations, Heidelberg, Dordrecht, London, New York: Springer.

Shimoda Y, Nagota T., Isayama N., Mizuno M. (2008) Verification of energy efficiency of district heating and cooling system by simulation considering design and operation parameters. Building and Environment, vol. 43, no 4, pp. 569-577.

Soliman S.A., Mantawy A.H. (2012) Modern Optimization Techniques with Applications in Electric Power Systems, Heidelberg, Dordrecht, London, New York: Springer.

Startbase (2014) Vnedrenie innovatsionnykh energosberegayushchikh PAV-tekhnologii daet oshchutimyi rezul'tat [Introduction of innovative energy-saving SAW technologies gives tangible results], 17.02.2014. Available at: http://www.startbase.ru/ knowledge/articles/336, accessed 19.06.2014.

State of Hawaii (2002) Sea water district cooling feasibility analysis for the State of Hawaii, Honolulu: State of Hawaii, Department of Business, Economic Development and Tourism, Energy, Resources, and Technology Division. Available at: http://www.districtenergy.org/assets/pdfs/03Innovative-Energy-Systems-Workshop-Honolulu/swac-full-report.pdf, accessed 19.06.2014.

Sweeney J.L. (2002) California Electricity Crisis, Stanford, CA: Hoover Institution Press Publication.

Tagare D.M. (2011) Electric power generation, New York: Wiley-IEEE Press.

Tidd J., Bessant J., Pavitt K. (2005) Managing Innovation Integrating Technological, Market and Organizational Change (3rd ed.), Chichester: Wiley\& Sons Ltd.

Weiers G. (2014) Innovation Through Cooperation: The Emergence of an Idea Economy, Heidelberg, Dordrecht, London, New York: Springer.

Wood A.J., Wollenberg B.F., Sheble G.B. (2013) Power generation, operation, and control (2nd ed.), New York: Wiley.

World Nuclear Association (2014) Nuclear Power in the USA. Available at: http://www.world-nuclear.org/info/CountryProfiles/Countries-T-Z/USA--Nuclear-Power/, accessed 19.06.2014.

Wu S. (2010) Heat energy storage and cooling in buildings. Materials for energy efficiency and thermal comfort in buildings (ed. M.R. Hall), Cambridge: Woodhead Publishing, pp. 101-126. 